\title{
Reflecting on the changing landscape of shareholder activism in South Africa
}

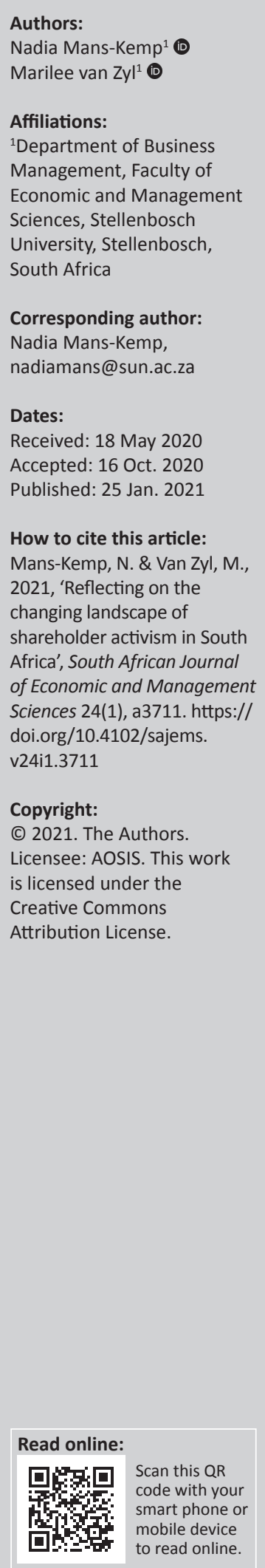

Background: Investors around the globe are increasingly focusing on investing in a responsible manner by accounting for environmental, social and corporate governance aspects alongside financial performance. Shareholder activism is a prevalent responsible investment strategy that is gradually gaining traction among South African investors.

Aim: The primary objective was to gauge the views of selected local institutional investors on the nature of shareholder activism endeavours in South Africa. The secondary objective was to offer suggestions on the way forward for shareholder activism considering rapid technological development and the COVID-19 pandemic.

Setting: South Africa offers a well-developed framework for responsible investors. Given their substantial shareholding, institutional investors in particular have considerable power to influence the practices and policies of investee companies.

Method: Semi-structured interviews were conducted with 13 representatives of local institutional investor organisations. Thematic analysis was conducted to analyse the primary data.

Results: Interviewees mostly engaged in private with investee companies on corporate governance issues. They explained that more information is required to meaningfully engage on social and environmental considerations. Participants indicated that they consider and employ public activism mechanisms if private engagements are deemed unsuccessful.

Conclusion: Technology will play an increasingly important role to enhance shareholder activism in future, but also offers various challenges. Although social media might be a valuable avenue to disclose information, it should be cautiously managed. Selective engagement details could be published on institutional investors' and companies' websites to enhance transparency regarding the nature and outcomes of engagements. Virtual and hybrid annual general meetings are likely to enable more shareholders to become active owners in future.

Keywords: shareholder activism; institutional investor; fourth industrial revolution; periods of crisis; COVID-19.

\section{Introduction}

Environmental, social and corporate governance (ESG) matters tend to come to the forefront during times of crisis, such as the 2008 global financial crisis (Sampei 2018) and the COVID-19 pandemic (Sparks 2020). Arjaliès (2010) confirmed that the 2008 crisis was a catalyst that considerably fuelled the responsible investment movement that aims to bring social responsibility to the asset management sector. According to Michael Fox (in Gordon 2020), a prominent ESG fund manager in the United Kingdom, COVID-19 'has done more for ESG [and by implication responsible investment] in 10 weeks than the last 10 years'.

Institutional and retail investors can employ several strategies, including screening and shareholder activism, to invest in a responsible manner by accounting for ESG aspects in addition to financial performance (Viviers et al. 2008). Positive and negative screening entails that certain companies are either included or excluded from an investment portfolio based on ESG considerations, while impact investors intend to achieve a positive socio-economic or environmental impact (Schueth 2003). Viviers and Els (2017) reported that the majority of local responsible investment funds focus on impact investing.

Loop, Bromilow and Malone (2018) remarked that 'activism is about driving change'. Shareholder activists could accordingly use their ownership position to influence the policies and practices of 
investee companies (Sjöström 2020). They can use voice and exit mechanisms to convey their dissatisfaction pertaining to financial and sustainability considerations to corporate leaders (McNulty \& Nordberg 2016). A voice mechanism refers to private or public engagement with management (McCahery, Sautner \& Starks 2016). Investors can alternatively utilise an exit mechanism by selling their shares in an investee company (Levit 2019). Given their large shareholding in multiple companies, institutional investors are a key force to bring about change in capital markets as they have considerable power to challenge corporate behaviour (Oh, Park \& Ghauri 2013; Organisation for Economic Co-operation and Development [OECD] 2011; Sandberg 2013). Institutional shareholder activism could hence be deemed a valuable governance mechanism to bring change in capital markets (Romano 2001).

South Africa has a history of pro-ESG initiatives, including the King reports on corporate governance, Regulation 28 and the Code for Responsible Investing in South Africa (CRISA). The country hence offers a well-developed framework to conduct responsible investment research. Principle 17 in the King IV report suggests that the governing bodies of institutional investors should ensure that responsible investment is practised to promote sound governance and value creation in investee companies (IoDSA 2016). Several local institutional investors, however, do not integrate ESG considerations into decision-making processes (Tomlinson, Bertrand \& Martindale 2017). Those that account for such considerations mainly focus on governance aspects (Feront \& Bertels 2019; Zhang 2016). Although most South African institutional investors publicly support responsible investment, actual changes to their investment policies are often superficial (Feront \& Bertels 2019).

A gradual increase has been seen in activism endeavours among institutional and retail investors due to South Africa's favourable regulatory environment (Deloitte 2019b). When reflecting on responsible investment in the country, the limited universe of listed companies and the fragmented pension fund market should be taken into account (Tomlinson et al. 2017). As such, local institutional investors prefer to engage in private on pressing matters (Viviers \& Smit 2015; Yamahaki \& Frynas 2016). They aim to avoid the potential negative impact on share prices and corporate reputation related to the application of public mechanisms (McCahery et al. 2016). Several corporate leaders also prefer private discussions, as these are deemed more constructive than public activism. The former allows activist institutional investors to negotiate solutions with boards or managers without necessarily jeopardising relationships (Viviers \& Smit 2015).

The fourth industrial revolution, characterised by increased usage of advanced technology to blend digital and physical environments, offers several opportunities and challenges for companies and their retail and institutional shareholders, including online meetings and management of personal information (Coulibaly 2020). The rapid spread of digital technology in the so-called age of transparency could considerably enhance shareholders' access to information and, by implication, informed decision-making (Coulibaly 2020). Enhanced transparency is of particular importance during periods of crisis (Lang \& Maffett 2011; Moon 2020). The impact of the fourth industrial revolution (Deloitte 2019a) and the COVID-19 pandemic (Gottfried \& Donahue 2020) on shareholder activism endeavours warrants investigation.

Semi-structured interviews were conducted with representatives from selected local institutional investors, given that they are extremely influential compliance officers whose actions have implications for a range of stakeholders (IoDSA 2016). The primary objective was to investigate their views on the nature of shareholder activism endeavours in South Africa. The secondary objective was to offer suggestions on the way forward for shareholder activism considering rapid technological development and the COVID-19 pandemic. Respondents' feedback was contextualised by accounting for changes pertaining to shareholder activism in response to the challenging and changing corporate circumstances, as highlighted in literature and the media. Guidance regarding ways to enhance the application and effectiveness of shareholder activism in future could be useful to respond to challenges and changes in times of crisis.

The theoretical framework and literature review are presented next, followed by a description of the qualitative methodology applied in the study. After a presentation of the results, recommendations will be offered to improve the application and effectiveness of shareholder activism mechanisms in light of the fourth industrial revolution and the COVID-19 pandemic.

\section{Theoretical framework}

The nature of shareholder activism, be it financial or social, depends on the goals of the activist and could be related to various theories explaining managerial behaviour. Social activism is linked to environmental and social issues, while financial activism is related to insufficient financial performance at investee companies (Goranova \& Ryan 2014). Jensen and Meckling's (1976) agency theory is deemed the primary theoretical lens in activism literature (Goranova \& Ryan 2014).

The agency theory is based on the complex relationships between principals (shareholders) and agents (managers). Although shareholders expect managers to optimally account for their interests, managerial actions might be driven by self-interest. If corporate agents focus on their own gains, the agency problem arises. In an attempt to minimise this problem and the associated costs, independent directors are supposed to monitor managerial actions and decisions. Several companies incentivise agents to guide their behaviour (Goranova \& Ryan 2014; Jensen \& Meckling 1976).

Local shareholder activists are, however, increasingly voicing their discontent regarding the perceived disconnect between 
managerial incentives and firm performance (Viviers et al. 2019). This perceived misalignment represents a lost opportunity to alleviate the agency problem (Ertimur, Ferri \& Muslu 2011). To mitigate the agency problem and asymmetric information, institutional investors should continually communicate with investee companies (Nix \& Chen 2013). Enhanced communication will ensure that alignment between the interests of a company and its shareholders is improved. As a result, investors' trust and confidence in investee companies are likely to increase (Nix \& Chen 2013).

While the agency theory is mainly linked to financial activism, social activism is related to the stakeholder theory (Goranova \& Ryan 2014). Freeman (1984) argued that shareholders form part of a diverse range of stakeholders who are affected by a company or have an influence on a company. The stakeholder theory thus postulates that corporate leaders should manage the complex relationships among a broad range of stakeholders, while cautioning against an excessive focus on shareholders' interests (Borlea \& Achim 2013).

The role of directors as corporate monitors, as suggested by the agency theory, should hence be reconsidered. Based on the stakeholder theory, it might be more apt to deem them mediators rather than corporate monitors (Lan \& Heracleous 2010). Shareholder activism is likely to increase the interaction between the owners and managers of a company and could result in positive outcomes for a range of stakeholders (McNulty \& Nordberg 2016). Some shareholders are, however, self-serving and likely to drive their own agenda at the cost of other stakeholders (Lan \& Heracleous 2010). Shareholder activists should thus be mindful of the benefits and costs related to their activism efforts (Gantchev 2013).

\section{Shareholder activism as a responsible investment strategy}

As explained in the introduction, responsible investors account for financial and ESG considerations that could influence long-term value creation for a range of stakeholders. Globally, a growing number of activist investors take ESG considerations into account. The percentage of institutional and retail investors that applied ESG principles to their investment decisions worldwide increased from $48 \%$ to $75 \%$ between 2017 and 2019 (Deloitte Insights 2020). Despite the country's well-developed responsible investment landscape, only a limited number of South African investors apply the responsible investment philosophy when making investment decisions (Viviers \& Els 2017).

\section{The local responsible investment landscape}

The responsible investment landscape in South Africa changed considerably over the last decade (2011 to 2020). The King IV report on corporate governance, Regulation 28 and CRISA had multiple implications for responsible investment policies and practices in the country (Viviers \& Els 2017).
A sound corporate governance framework is critical in attracting investors for economic growth and can substantially enhance investor confidence (Beekes \& Brown 2006). The King report can be seen as a form of 'soft law regulation' to guide sustainable behaviour (Esser 2017). Compliance with the King guidelines is voluntary, but listed companies must comply with these guidelines as part of the Johannesburg Stock Exchange (JSE) listings requirements (JSE 2017).

The local stock exchange also launched the JSE Socially Responsible Investment (SRI) index (now called the FTSE/JSE Responsible Investment Index Series) in 2004 to identify listed companies that integrate triple bottom principles into their activities, and to facilitate investment in such companies (JSE 2015). The performance of locally listed companies is annually reviewed against a set of ESG considerations to determine constituency. Since then, the index series evolved considerably to further promote sustainable development (JSE 2015).

In addition to the publication of the pioneering King report, South Africa was the second country in the world to formally encourage institutional investors to consider ESG aspects when making investment decisions (Deloitte \& Touche 2014). Regulation 28 of the Pension Funds Act (No. 24 of 1956) was revised in 2011 to ensure that retirement funds meet long-term obligations to their members by obliging institutional investors to account for ESG factors (Deloitte \& Touche 2014).

Furthermore, CRISA was published in 2011 to guide the investor community to give effect to the King III report and the United Nations-supported Principles for Responsible Investment (UN PRI) initiative (Deloitte \& Touche 2014; IoDSA 2011). This code postulates that organisations that exhibit sound corporate governance practices are expected to create value in a sustainable manner. The term 'value' does not only refer to financial aspects, but includes social and environmental aspects (IoDSA 2011). When CRISA was launched, the former South African Minister of Finance, Pravin Gordhan, remarked that the 2008 financial crisis emphasised the importance of a longer-term investment focus (Deloitte \& Touche 2014). The process to revise CRISA commenced in 2020.

The UN PRI offers guidance to investors around the globe to invest in a responsible manner over the long run. The majority of the local signatories are investment managers and service providers (Tomlinson et al. 2017). Prominent asset owners such as the Government Employees Pension Fund perform an important role in developing scheme practices that smaller local pension schemes can adopt (Tomlinson et al. 2017). Ertimur et al. (2011) confirmed that institutional investors can leverage other (minority) shareholders' support by setting an example.

Given their power, institutional investors can be a considerable driving force for improved performance (Ivanova 2017). Institutional investors are such influential stakeholders that the King IV report includes a specific principle to highlight 
their primary responsibilities (IoDSA 2016). King IV proposes that an institutional investor's governing body should provide direction for responsible investment and approve policies in this regard. Institutional investors should furthermore disclose their code on responsible investing and details on the application thereof (IoDSA 2016). The guidance note published by the Financial Sector Conduct Authority (2019) sheds more light on sustainable investments and assets in the context of retirement funds' investment policy statements.

Based on an extensive review of the changing ESG landscape in South Africa, Tomlinson et al. (2017) encouraged the Financial Sector Conduct Authority to cautiously review the mandates of investment managers to ensure that they reflect the expectations for investment practice as set out in Regulation 28. They indicated that CRISA could benefit from appointing a permanent secretariat to enhance its stewardship. Emphasis was placed on the inclusion of ESG aspects as part of trustee training. They furthermore suggested that investors should be educated on the application of different ESG approaches. Given that enhanced transparency aids informed decision-making, it is likely that the Financial Sector Conduct Authority and the JSE will place even more focus on the quality of disclosure on material ESG factors in future (Tomlinson et al. 2017).

\section{Reflecting on shareholder activism mechanisms}

Responsible investors can employ three main strategies, namely screening, impact investing and shareholder activism. In this study, focus is placed on shareholder activism, with pertinent reference to the South African context. As explained in the introduction, shareholder activists aim to influence the behaviour of investee companies by exercising their rights as owners. They can employ a range of private and public voice mechanisms to focus attention on financial and ESG considerations (Schueth 2003). As the name implies, private engagements occur behind the scenes, such as writing emails or arranging confidential negotiations with key decisionmakers of investee companies. In contrast, public voice mechanisms include raising concerns at annual general meetings (AGMs), voting and filing shareholder resolutions. Shareholders can also engage in debate via traditional and social media. Proxy voting furthermore enables shareholders to delegate voting power to delegate voting power to a representative (Viviers \& Smit 2015).

Alternatively, an investor can opt to exit from an investee company by selling their shares. If an institutional investor employs this mechanism, it signals dissatisfaction to other shareholders and could have a devastating impact on a targeted company's share price (Levit 2019). When several shareholders divest concurrently, the investee company's market capitalisation and cost of capital might be severely affected (Gillan \& Starks 2003). Given the size of the South African share market, a limited number of local shareholders have utilised this mechanism (Viviers \& Smit 2015). Some researchers deem the mere threat of exit sufficient to signal their discontent with an investee company's actions, policies and practices, without having potential detrimental consequences for a range of stakeholders (Admati \& Pfleiderer 2009; Levit 2019; McCahery et al. 2016).

The selection of a specific engagement mechanism depends to a large extent on the investor's ability to gain access to the investee company's management. Large institutional investors typically prefer private mechanisms. If private engagement is deemed unsuccessful, they consider (more hostile) public shareholder activism mechanisms (McCahery et al. 2016). A growing number of activist South African investors are voicing their concerns in public. For instance, several shareholders publicly opposed perceivably excessive executive compensation at multiple local companies in 2020 (Just Share 2020a). Despite the increase in emolument-related shareholder activism, only a few executives announced that they were willing to take a pay cut following the South African lockdown related to COVID-19. Likewise, only a limited number of institutional fund managers responsible for the pensions of millions of South Africans have made public commitments to cut their salaries and make donations to the so-called Solidarity Fund (Just Share 2020a).

Previous scholars assessed the effectiveness of public activism endeavours globally (Cai \& Walkling 2011; Kimbro \& Xu 2016) and locally (Viviers et al. 2019; Viviers \& Smit 2015). Based on a review of 24510 votes cast by 17 South African investment managers and interviews with selected investment managers, Viviers and Smit (2015) reported that proxy voting was deemed a last resort in the local context. Less than $7 \%$ 'against' votes were recorded, mainly pertaining to executive remuneration. They furthermore noted that companies that were excluded from the FTSE/JSE SRI index attracted more shareholder opposition than constituents (Viviers \& Smit 2015). Bauer, Moers and Viehs (2015) assessed the determinants of withdrawal of shareholder proposals in the United States and reported that proposals filed by influential institutional investors were more likely to be withdrawn than those filed by private investors. There is a limited body of research on private engagements between institutional investors and investee companies, given the confidential nature thereof (Semenova \& Hassel 2019). There is hence scope to assess institutional investors' selection and application of specific activism mechanisms in South Africa.

The fourth industrial revolution and the COVID-19 pandemic have multiple implications for shareholder activism endeavours, as explained next.

\section{Exploring the potential impact of the fourth industrial revolution and the COVID-19 pandemic on shareholder activism endeavours}

Rapid technological developments have multiple implications for listed companies and their shareholders (Goldman Sachs 2019; Uldam 2018). COVID-19 furthermore forced companies to reconsider the way in which they engage with shareholders, inter alia, due to challenges associated with social distancing (Kennedy-Good \& Chalwin-Milton 2020). 
Shareholder activists are increasingly moving from traditional media platforms such as newspapers to social media, including Twitter, to raise their concerns and enhance awareness of corporate issues (Uldam 2018). Although the usage of social media gives users unprecedented visibility, online security and the protection of personal information are prominent concerns (Uldam 2018). The long-lasting impact of negative comments raised in the media on companies' reputations should also be considered (Chartered Governance Institute of Southern Africa 2020). The King IV report confirmed that the increased usage of social media platforms will radically enhance transparency. Governing bodies are hence urged to ensure sufficient oversight of technology and information management. Proactive monitoring will enable them to timeously respond to adverse social media events (IoDSA 2016).

Annual general meetings are essential corporate events that allow shareholders the opportunity to share their views and receive feedback from corporate leaders (Kennedy-Good \& Chalwin-Milton 2020). Shareholders also cast their votes on tabled resolutions, either in person or via proxies. A surge was noted in proxy voting in 2009 following the 2008 global financial crisis (Gottfried \& Donahue 2020). A similar trend is expected following the COVID-19 pandemic. Although technological developments associated with the fourth industrial revolution enabled companies to facilitate online meetings and voting for some time, local companies still opted for in-person meetings until March 2020. Social distancing as a result of COVID-19, however, brought about considerable challenges to facilitate in-person meetings and engagements. Local legislation allows for electronic AGMs if reasonable participation and simultaneous discussion among attendees are possible (Chartered Governance Institute of Southern Africa 2020; Kennedy-Good \& Chalwin-Milton 2020). Electronic meetings are, however, not a possibility if a company's memorandum of incorporation prohibits such events (Kennedy-Good \& Chalwin-Milton 2020). As such, several local companies had to postpone their in-person AGMs during 2020 (Larkin 2020).

In response, the JSE (2020) in collaboration with The Meeting Specialist launched a platform that enables listed companies to hold virtual AGMs and conduct electronic voting. In addition to complying with a legal requirement to facilitate a mandatory yearly shareholder gathering, this pioneering initiative allows shareholders to participate in AGMs irrespective of their location, by using a range of technological devices at their disposal. Virtual meeting attendance is furthermore cost-effective, as shareholders and board members are not required to travel (JSE 2020). An executive director at Alexander Forbes, the first company that made use of The Meeting Specialist's platform, remarked that in due course, virtual meetings will become a routine addition to conventional meetings (JSE 2020:1). Companies that plan to conduct virtual meetings should ensure that their online facilities are easily accessible and can deal with a large number of individuals concurrently attempting to $\log$ in (Kennedy-Good \& Chalwin-Milton 2020).
The local non-profit shareholder activist organisation Just Share (2020b) recognised that virtual AGMs are reasonable, given restrictions imposed by the COVID-19 pandemic. Just Share, however, cautioned JSE-listed companies against infringing shareholder rights and non-compliance with the Companies Act (No. 71 of 2008) when opting for online meetings. They furthermore expressed concern that shareholders' questions might be moderated before being submitted to directors. As such, Just Share urged listed companies to ensure meaningful, real-time shareholder participation in future.

Shareholder activists could arguably use the case of COVID-19 to illustrate why specific ESG-related changes are essential, in particular related to board composition and the perceived disconnect between executive pay and performance (Gottfried \& Donahue 2020). Some shareholders might, however, question whether they should challenge companies that are already experiencing considerable financial hardship owing to share markets around the globe being under severe pressure (Orol 2020). Given that a stable macroeconomic environment is a prominent catalyst of shareholder activism, the ultimate impact of the COVID-19 pandemic on shareholder activism remains uncertain (Gottfried \& Donahue 2020) and requires further investigation. This study was conducted to shed light on the way forward for shareholder activism in South Africa.

\section{Research design and methodology}

The authors gauged selected South African institutional investors' views on shareholder activism. This research formed part of a broader study, covering corporate governance developments in South Africa, given the King IV publication and its focus on institutional investors. As mentioned, institutional shareholder activism is a valued corporate governance mechanism (Romano 2001). The target population comprised all local institutional investors. Given that the largest institutional investors are typically pension funds and the fragmented nature of the local pension fund industry comprising more than 3000 funds (Tomlinson et al. 2017), it was impractical to conduct interviews with all local institutional investors. Non-probability sampling was hence employed. Asset managers who directly invest in locally listed bonds and equities formed part of the sample frame. The researchers employed a combination of judgement and snowball sampling to select participants. An industry contact assisted the researchers to make initial contact with potential participants. Thereafter, snowball sampling was used based on referrals from interviewees.

A number of previous researchers employed qualitative methods when assessing shareholder activism (including Adegbite, Amaeshi \& Amao 2012; Tomlinson et al. 2017; Yamahaki \& Frynas 2016), as the phenomenological paradigm allows in-depth analysis of participants' views. The usage of semi-structured interviews gives researchers more control over the quality of the collected data, as uncertainties can be clarified by posing open-ended and theoretically motivated 
questions (Galletta 2013). Semi-structured interviews were conducted with 13 representatives from 12 local institutional investors to gauge their views on the nature of shareholder activism in the country. One of the interviewees requested that their risk assurance manager participate during a joint interview. Given that there is no 'ideal' sample size for qualitative research, focus should be placed on the adequacy of selected participants (O'Reilly \& Parker 2013). As their industry experience ranged from 6 to 26 years (16 years on average), participants offered informed opinions and extensive feedback on the topic under investigation. The institutional investors' approximate size of assets under management ranged between R200 million and R630 billion (average of R252.8 billion) at the stage when the interviews were conducted.

To enhance confirmability and to ensure that relevant questions were included, the interview guide was discussed with three corporate governance experts prior to conducting the interviews. A funnel interviewing technique was employed: after participants expressed broad viewpoints, they were encouraged to offer more focused responses. Clarifying questions were asked in some instances to ensure that participants' views were accurately captured. Interviewees answered questions pertaining to the institutional investors that they represent, including whether they are a signatory of the UN PRI and subscribe to CRISA. They were also requested to indicate what they consider to be the biggest implications of publicly proclaiming to be a responsible investor.

Examples of main and additional clarifying questions (in brackets) that were included in the interview guide include:

- Do you engage with investee companies on behalf of your clients? (Which form of shareholder activism do you consider to be most efficient to promote change, private or public? Please motivate your answer.)

- Are the stakeholder engagement processes of investee companies efficient in creating a platform for stakeholders to discuss their concerns? (How do you think investee companies can improve their stakeholder engagement processes to make it easier for stakeholders to raise their concerns?)

- Do you think that shareholder activism in South Africa will be able to 'enforce' efficient compliance to the King IV guidelines? (Do you think social media can play a role to enhance stakeholder inclusion?)

The interview guide and informed consent form were distributed to participants prior to conducting the interviews. They were requested to provide their biographical details and answer questions related to their employer via email before the interviews took place. Seven of the interviews were conducted in person and the remainder via teleconference. The interviews ranged between 40 and 90 minutes in duration. Although participants had the option to decline to answer questions and withdraw from the study at any stage, none of them opted to withdraw.
Permission was requested from each interviewee to transcribe their interview. Braun and Clarke's (2006) six-step thematic analysis approach was employed to derive themes from the transcribed data. The six-step process entailed that one of the researchers first familiarised herself with the collected data. Secondly, initial coding took place by assigning preliminary codes, based on the meaningful data features to offer an indication of the context of the interviews. Thirdly, preliminary themes and sub-themes were identified. Inductive coding was applied. Fourthly, the identified themes were reviewed and discussed by the researchers whereafter they were finalised (step 5). The final step entailed that conclusions were formulated based on the themes related to shareholder activism. Participants' responses were contextualised, given changes in the corporate landscape in response to the fourth industrial revolution and the COVID-19 pandemic.

To enhance the credibility of the findings, some interviewees were contacted to confirm that their views were accurately conveyed in the transcription. Pertaining to the dependability criterion of trustworthiness, the study can be replicated in future by following the outlined approach. Transferability was addressed by offering details on the research context to allow reflection on the applicability thereof in other settings.

Inferential validity was accounted for by using the King IV report, CRISA and applicable literature to develop the interview guide and interpret the results. Attention was also given to thematic analytical validity by including data extracts to support the themes that were derived.

\section{Ethical consideration}

Ethical clearance was obtained to conduct this study from the Research Ethics Committee (REC) of Stellenbosch University. Project number: 6906.

\section{Results and discussion}

An interviewee raised the view that shareholder activism in South Africa is 'picking up momentum' due to institutional investors being 'forced', through CRISA and the UN PRI, to apply ESG principles and to scrutinise the governing bodies of investee companies. The Chartered Governance Institute of Southern Africa (2020) confirms that shareholder activism is gaining momentum in the country. Participants were requested to state whether the institutional investor that they were affiliated with was a signatory to the UN PRI and subscribed to CRISA when the interview was conducted. This body and code have prominent implications for responsible investors (Deloitte \& Touche 2014). Seven of the institutional investors were signatories to the UN PRI and eight subscribed to CRISA. One institutional investor originated from a large institution that was a signatory to the UN PRI. A participant explained that this institutional investor 'takes the matter of RI [responsible investment] seriously, but it requires a lot of focus, attention, people and resources'. As such, this participant noted that the 
institutional investor will subscribe to CRISA 'when they have the capacity to do so'.

Two institutional investors supported and followed the principles outlined by the UN PRI and CRISA without becoming a signatory or officially subscribing to the code. Another participant remarked that CRISA has 'a higher degree of relevance for local institutional investors' (than the UN PRI), given that their investors are largely SouthAfrican-based. As such, this institutional investor did not regard it necessary to become a signatory to the UN PRI, given the subscription to CRISA. The interviewee indicated that this decision would be reconsidered as the institutional investor grows, more offshore investors are included in their investor base and due to pressure from investors. Tomlinson et al. (2017) emphasised the importance of growing market awareness of ESG investment approaches.

Most of the participants were, however, not convinced that South African shareholder activists will be able to enforce corporate governance compliance, as suggested in King IV (IoDSA 2016). Principle 17 in this report is specifically applicable to institutional investors. All the participants stated that they are supportive of this principle. It was highlighted by four participants that they believe that institutional investors that subscribe to CRISA, and actively apply its guidelines, will be able to comply with Principle 17 of King IV. Several of the participants were of the opinion that their employers were already complying with this principle by actively pursuing CRISA. An interviewee remarked that Principle 17 made their client base more aware of responsible investing.

Details will now be provided on the shareholder activism themes that emerged from the thematic analysis.

\section{Participants' views on responsible investor status}

Participants expressed contrasting views on whether responsible investor status should be publicised. Four participants stated that a public declaration in this regard is mostly 'window dressing'. The other participants argued that a mere proclamation of responsibility is not sufficient; it should be visible in actions. Goh (2018) agreed that it is debatable whether a mere proclamation will truly result in improved behaviour. The difference between intent and actual corporate actions may tarnish a company's reputation (Greyser 2009).

An interviewee remarked that 'actions speak louder than words'. If investors fail to act in a responsible manner, it will become known regardless of whether or not they proclaim to be responsible investors. A counterpart added that such practices must be 'imbedded in your culture and investment philosophy'. This view is supported by the King IV report (IoDSA 2016). A related opinion was raised by an interviewee: 'transparency is really important for driving behaviour'. Sufficient information on financial and non-financial performance should hence be shared with stakeholders. By definition, responsible investors aim to incorporate financial and sustainability information when making investment decisions (Viviers et al. 2008). A participant, however, warned against undue pressure by clients to deliver superior investment performance. An excessive focus on financial considerations contradicts the responsible investment philosophy. The rapid spread of digital technology could considerably enhance transparency (Coulibaly 2020) which is of particular relevance during periods of crisis (Lang \& Maffett 2011; Moon 2020).

\section{Views on applying public versus private shareholder activism mechanisms}

The majority of the interviewees indicated that they prefer private engagements, as public activism is typically confrontational and hostile in nature. The view was raised that shareholders are not 'active enough' which makes interaction challenging. Yamahaki and Frynas (2016) and Viviers and Smit (2015) confirmed that shareholder activism typically occurs behind closed doors in the country, given the confidential nature of discussions. This tendency might also be partly ascribed to the country's limited investment universe (Tomlinson et al. 2017) and the subsequent drive to protect relationships with investee companies (Viviers \& Smit 2015). In an attempt to enhance transparency, several participants mentioned that they provide some information on engagements in reports that are made available on their websites. The shareholder activist Just Share (2020b) encourages other institutional investors to follow suit.

Ten participants (more than $75 \%$ of the sample) suggested that institutional activists should initially consider a private mechanism, such as engagement. If the investee company does not respond, or if the private engagement is not deemed successful, the institutional investor can consider employing public mechanisms. McCahery et al. (2016) shared this view. A possible reason for the preference for private engagements is that public activism could be rather costly (Admati \& Pfleiderer 2009). Activist investors often only enjoy a fraction of the benefits negotiated by them. The related free-rider problem implies that all shareholders might benefit if one investor publicly raises concerns, although they do not bear any costs or engage themselves (Gillan \& Starks 2000). Due to institutional investors' large stakes in investee companies, they might be able to cover the associated costs when there is a possibility of significant returns as a result of their activism endeavours (Gillan \& Starks 2000). Another possibility mentioned by an interviewee is 'semi-private' engagements in which stockbrokers invite portfolio managers to engage with a company's management in a group meeting. Other participants deemed public activism endeavours more effective than private engagements, given that the responses 'are there for the public to see'.

Participants concurred with Viviers and Theron (2019) that public shareholder activism might have considerable 
negative repercussions for institutional investors. The example of Futuregrowth Asset Management was mentioned by several participants. After publicly proclaiming that they would not issue new loans to state-owned enterprises (SOEs) given governance-related concerns, Futuregrowth withdrew their support pending review of the SOEs' governance structures. Some of the SOEs' credit ratings were subsequently downgraded (Viviers \& Theron 2019). After several engagements, Futuregrowth announced that they would resume lending to specific SOEs. Their public shareholder activism approach was received in a negative and emotive light, since trust was compromised. This is a prime example of good intentions of an institutional investor being perceived incorrectly. Given the outcome of this case, asset managers might be encouraged to rather pursue private engagements (Viviers \& Theron 2019).

Shareholder activism research suggests that it is beneficial to form coalitions with other stakeholders (Sjöström 2020). Participants, however, expressed concern about the implications of the acting in concert provision included in the Companies Act (No. 71 of 2008). To act in concert means:

Any action pursuant to an agreement between or among two or more persons, in terms of which any of them co-operate for the purpose of entering into or proposing an affected transaction or offer. (Republic of South Africa 2009: 212)

Interviewees implied that this provision has a major implication for shareholder activism, as it makes it difficult for institutional investors to coordinate with other shareholders to initiate change.

In the light of rapid technological developments associated with the fourth industrial revolution, several participants mentioned that social media should be employed to create and enhance awareness of topical issues. Uldam (2018) confirm that social media is increasingly used by activists, often with devastating outcomes for corporate reputations (Chartered Governance Institute of Southern Africa 2020). Concerns were likewise raised by participants about expressing views on social media, especially Facebook and Twitter, that could be interpreted out of context. An interviewee argued that, as these platforms can 'disrupt the control of the corporate narrative that the company may think it has', they can be detrimental to an entity's reputation and brand. The view was expressed that media statements are often blown out of proportion as stakeholders might 'read their own personal bias into it'. This finding supports the King IV recommendation that social media should be proactively monitored (IoDSA 2016). A chief information officer can be appointed to assist in this regard (Maruca 2000). It is likely that more focus will be placed in future on the impact of brand trust on the relationships between a business and its stakeholders (Davis \& Mulcahy 2018).

\section{Engagement frequency and prevalent topics}

Eight participants (more than $60 \%$ of the sample) stated that the frequency of engagements varies due to the considerable number and nature of issues that require attention. Followup meetings with management of investee companies to reflect on the success of engagements were brought up by five interviewees. Semenova and Hassel (2019) likewise reported that Nordic institutional investors mentioned follow-up private engagements if an engagement case has not been closed within two months.

The interviewees indicated that engagements mainly centred on executive remuneration concerns. Engagements on board composition were also mentioned. An interviewee referred to voting on executive remuneration as 'a good example of what you can achieve if you want shareholder activism to play a more prominent role'. A counterpart suggested that 'roadshows' could be held to facilitate robust discussions with large investors on executive remuneration. Literature confirms that shareholder activism in South Africa is primarily eventdriven and focused on corporate governance issues such as emolument and board diversity (Davids \& Kitcat 2019; Viviers, Mans-Kemp \& Fawcett 2017; Viviers et al. 2019). This tendency could be partly ascribed to the introduction of say-on-pay guidelines and board diversity targets in King IV (IoDSA 2016). A participant ascribed the focus on the G-component of ESG to governance information being more accessible than data on social and environmental considerations. This participant stressed that more information is required to ensure meaningful engagement on sustainability topics in future. This call by participants is echoed by researchers (Eccles \& Klimenko 2019).

\section{Suggestions to enhance engagement and facilitate change}

An interviewee remarked that clients should pressurise companies to improve their engagement processes in future. It was suggested by this participant that contracts should be amended to offer more details on the expected behaviour of the institutional investor on behalf of the client. Although Viviers and Smit (2015) indicated that proxy voting seems to be the last resort for local shareholder activists, an interviewee expressed the view that proxy voting is expected to gain more traction in future: 'it's a two-way street; the institutional investors move on their own accord, but they will need the pressure from clients'. Gottfried and Donahue (2020) confirmed that it is likely that this shareholder activism mechanism will receive more attention following the disruption in markets caused by the COVID-19 pandemic.

The participants provided several recommendations on how to improve engagements in future, given rapid technological advancement. They deemed AGMs a prominent engagement platform, in addition to semi-annual and annual results presentations. The view was expressed by an interviewee that 'companies can use technology a lot more through webcasts'. By presenting a company's results and AGM via webcasts, more shareholders would be able to engage in discussions. Purcell (2008) suggested that electronic communication channels will not only result in more 
effective engagements and better representation at meetings, but shareholders will also have the opportunity to vote directly without going through a proxy. Despite such calls, the first platform to facilitate electronic AGMs in South Africa was only introduced by the JSE (2020) in March 2020 following the COVID-19 pandemic that brought about social distancing. The impact of technology on shareholders' preference for specific activism mechanisms warrants further investigation.

\section{Conclusions and recommendations for future research}

South Africa provides a well-developed framework to conduct research on responsible investment, including the King IV report, CRISA and Regulation 28. Responsible investors can employ a range of strategies, including shareholder activism, to account for ESG and financial considerations when making investment decisions. An increase in shareholder activism endeavours are noted among local shareholders of all sizes. Given their considerable shareholding in listed companies, institutional investors in particular can have a substantial impact in encouraging more responsible corporate behaviour. Despite a range of public and private voice mechanisms at their disposal, literature indicates that local institutional investors prefer engaging in private with investee companies, mainly to protect the latter's reputation. This study was conducted to investigate the views of selected institutional investors on the nature of shareholder activism endeavours in South Africa by conducting semi-structured interviews. The secondary objective was to contextualise their feedback by accounting for the impact of the fourth industrial revolution and the COVID-19 pandemic on the way forward for shareholder activism endeavours.

The results of the thematic analysis show that the majority of the interviewees preferred private engagements, as they deemed public activism to be too confrontational. Several participants were discouraged to engage in coalitions to drive change, given the acting in concert provision provided for in the Companies Act (No. 71 of 2008). Regular engagements and follow-up discussions with the management and directors of investee companies were mentioned. Some interviewees stated that engagement details are shared on the investee company's website. Based on these findings, it is suggested that more institutional investors should follow suit. Enhanced transparency will enable a broader range of stakeholders, including minority shareholders, to make more informed decisions.

The majority of the interviewees were of the view that shareholder activists will not be able to enforce compliance with the King IV guidelines, despite an acknowledgement in this report that they are deemed the ultimate compliance officers. Engagements were largely focused on corporate governance concerns, in particular executive remuneration and board composition. Interviewees remarked that more information is required to meaningfully engage on social and environmental aspects. If more clients apply pressure on institutional investors, and they in turn engage more frequently with investee companies, it can be a tipping point for shareholder activism in South Africa. Technological systems and devices are likely to be considerable enablers in this regard. Interviewees indicated that social media could be valuable to enhance awareness of material ESG information, but might have potential detrimental consequences if quoted out of context. A chief information officer could assist to properly manage social media.

Participants furthermore indicated that the format of AGMs should be reconsidered. They suggested that technology could be utilised more extensively to enhance shareholder participation. This suggestion is particularly apt in the light of the COVID-19 pandemic. Webcast AGMs, hybrid meetings (in-person meetings that are simultaneously webcast) and virtual results presentations will enable more shareholders to become active owners. Shareholders will have to rethink the application and effectiveness of the mechanisms at their disposal to ensure that their voices are heard, while simultaneously being sensitive not to (further) endanger the livelihood of companies given challenging economic circumstances.

Based on the reported results, and in line with the views of Just Share (2020b) and Kennedy-Good and Chalwin-Milton (2020), the following guidelines are suggested for virtual AGMs and hybrid meetings in future:

- Shareholders should be timeously informed about meetings and technical arrangements, such as login details, and how to cast their votes.

- Platforms should be able to accommodate a large number of participants to log in within a short time period. The functionality of platforms should be tested before a meeting takes place.

- In addition to electronic questions, shareholders should have the option of submitting questions verbally, in real time, without moderation.

- Sufficient time should be allocated for the question and answer session by accounting for potential technological challenges. Technological support should be available during the entire meeting to address challenges.

- A summary of the questions and answers covered during an AGM could be published on the company's website to inform other stakeholders.

A similar study can be conducted in future to determine longitudinal changes related to shareholder activism endeavours in response to the COVID-19 pandemic and rapid technological development by reflecting on, inter alia, the employed measures and outcomes. While this study centred on institutional investors, interviews can be conducted with institutional and retail investors. The views of trade union representatives might also be gauged, given the considerable social impact of the pandemic. Surveys could also be considered to gauge these stakeholders' views on activism endeavours. Researchers can, furthermore, give 
attention to changes related to corporate risk oversight and the management of investor relations in response to periods of crisis.

\section{Acknowledgements Competing interests}

The authors have declared that no competing interest exists.

\section{Authors' contributions}

N.M.-K. conceptualised and wrote the article. M.v.Z. conducted the interviews and the thematic analysis. She also contributed to the literature review and the finalisation of the article.

\section{Funding information}

This research received no specific grant from any funding agency in the public, commercial or not-for-profit sectors.

\section{Data availability statement}

The data will not be made publicly available to protect the privacy of the research participants.

\section{Disclaimer}

The views and opinions expressed in this article are those of the authors and do not necessarily reflect the official policy or position of any affiliated agency of the authors.

\section{References}

Adegbite, E., Amaeshi, K. \& Amao, O., 2012, 'The politics of shareholder activism in Nigeria', Journal of Business Ethics 105(3), 389-402. https://doi.org/10.1007/ s10551-011-0974-y

Admati, A.R. \& Pfleiderer, P., 2009, 'The "Wall Street walk" and shareholder activism: Exit as a form of voice', The Review of Financial Studies 22(7), 2645-2685. https:// doi.org/10.1093/rfs/hhp037

Arjaliès, D.-L., 2010, 'A social movement perspective on finance: How socially responsible investment mattered', Journal of Business Ethics 92(1), 57-78. https:// doi.org/10.1007/s10551-010-0634-7

Bauer, R., Moers, F. \& Viehs, M., 2015, 'Who withdraws shareholder proposals and does it matter? An analysis of sponsor identity and pay practices', Corporate
Governance: An International Review 23(6), 472-488. https://doi.org/10.1111/ Governance:

Beekes, W. \& Brown, P., 2006, 'Do better-governed Australian firms make more informative disclosures?', Journal of Business Finance \& Accounting 33(3), 422-450. https://doi.org/10.1111/j.1468-5957.2006.00614.x

Borlea, S.N. \& Achim, M.V., 2013, 'Theories of corporate governance', Economics Series 23(1), 117-128.

Braun, V. \& Clarke, V., 2006, 'Using thematic analysis in psychology', Qualitative ResearchinPsychology3(2),77-101.https://doi.org/10.1191/1478088706qp063oa

Cai, J. \& Walkling, R.A., 2011, 'Shareholders' say on pay: Does it create value?', Journal of Financial and Quantitative Analysis 46(2), 299-339. https://doi.org/10.1017/ of Financial and Quantion

Chartered Governance Institute of Southern Africa, 2020, CGISA best practice guide: Shareholder activism and the role of the company secretary, viewed 11 September 2020, from https://chartsec.co.za/documents/members/CGISA\% 20Best $\% 20$ Practice $\% 20$ Guide $\%$ 20Shareholder\%20Activism.pdf.

Coulibaly, B.S. (ed.), 2020, 'Foresight Africa: Top priorities for the continent 2020-2030', Africa Growth Initiative at Brookings, viewed 13 May 2020, from https://www. brookings.edu/wp-content/uploads/2020/01/ForesightAfrica2020_20200110.pdf.

Davids, E. \& Kitcat, R., 2019, 'The shareholder rights and activism review. South Africa', The Law Reviews, viewed 25 April 2020, from https://thelawreviews. co.uk/edition/the-shareholder-rights-and-activism-review-edition-4/1197511/ south-africa.

Davis, N. \& Mulcahy, S., 2018, 'The power of trust and values in the fourth industrial revolution', World Economic Forum, viewed 13 May 2020, from https://www. weforum.org/agenda/2018/10/power-trust-and-values-fourth-industrialrevolution/.
Deloitte, 2019a, Taking the long-term view: 2019 directors' alert, viewed 12 May 2020, from https://www2.deloitte.com/content/dam/Deloitte/pe/Documents/ 2020, from https://WwW2.deloitte.com
risk/Directors\%20Alert\%202019.pdf.

Deloitte, 2019b, 'Be your own activist': How boards can develop an activist mindset to drive secure value, viewed 12 May 2020, from https://www2.deloitte.com/ content/dam/Deloitte/za/Documents/finance/ActivistShareholder_Pamphlet.pdf.

Deloitte Insights, 2020, Advancing environmental, social, and governance investing: A holistic approach for investment management firms, viewed 15 March 2020, from https://www2.deloitte.com/content/dam/insights/us/articles/5073_AdvancingESG-investing/DI_Advancing-ESG-investing_UK.pdf.

Deloitte \& Touche, 2014, The relationship between CRISA and Regulation 28 of Pension Funds Act and integrated reporting, viewed 21 January 2018, from https://www2. deloitte.com/content/dam/Deloitte/za/Documents/governance-risk-compliance/ ZA_TheRelationshipBetweenCRISAAndRegulation280fPensionFundsAct 040̄2014.pdf.

Eccles, R.G. \& Klimenko, S., 2019, 'The investor revolution', Harvard Business Review, May/June, viewed 14 May 2020, from https://hbr.org/2019/05/the-investorrevolution.

Ertimur, Y., Ferri, F. \& Muslu, V., 2011, 'Shareholder activism and CEO pay', Review of Financial Studies 24(2), 535-592. https://doi.org/10.1093/rfs/hhq113

Esser, I.-M., 2017, 'Corporate governance: Soft law regulation and disclosure - The cases of the United Kingdom and South Africa', in J.J. Du Plessis \& C.K. Low (eds.), Corporate governance codes for the 21st century: International perspectives and critical analyses, pp. 233-260, Springer, Cham.

Feront, C. \& Bertels, S., 2019, 'The impact of frame ambiguity on field-level change' Organization Studies. December 2019, pp. 1-31. https://doi.org/10.1177/ 0170840619878467

Financial Sector Conduct Authority, 2019, Guidance notice: Sustainability of investments and assets in the context of a retirement fund's investment policy statement, viewed 15 May 2020, from https://justshare.org.za/wp-content/ uploads/2019/07/FSCA-Guidance-Notice-1-of-2019-PFA-Sustainability-ofInvestments-and-Assets.pdf.

Freeman, R.E., 1984, Strategic management: A stakeholder approach, Pitman, Boston, MA.

Galletta, A., 2013, Mastering the semi-structured interview and beyond: From research design to analysis and publication, New York University Press, New York, NY.

Gantchev, N., 2013, 'The costs of shareholder activism: Evidence from a sequential decision model', Journal of Financial Economics 107(3), 610-631. https://doi. org/10.1016/j.jfineco.2012.09.007

Gillan, S.L. \& Starks, L.T., 2000, 'Corporate governance proposals and shareholder activism: The role of institutional investors', Journal of Financial Economics 57(2) 275-305. https://doi.org/10.1016/S0304-405X(00)00058-1

Gillan, S.L. \& Starks, L.T., 2003, 'Corporate governance, corporate ownership, and the role of institutional investors: A global perspective', Journal of Applied Finance 13(2), 4-22. https://doi.org/10.2139/ssrn.439500

Goh, J., 2018, Some ESG strategies 'just window dressing', viewed 18 August 2018, from https://expertinvestoreurope.com/selector-most-esg-criteria-is-just-windowdressing/.

Goldman Sachs, 2019, 'Shareholder engagement in the age of transparency', GS Sustain ESG Series, 12 June, viewed 12 May 2020, from https://www.eticanews.it/ wp-content/uploads/2019/06/Shareholder-engagement-in-the-age-oftransparency-1.pdf.

Goranova, M. \& Ryan, L.V., 2014, 'Shareholder activism: A multidisciplinary review', Journal of Management 40(5), 1230-1268. https://doi.org/10.1177/014920 6313515519

Gordon, J., 2020, 'Royal London's Fox: “Covid has done more for ESG in 10 weeks than the last 10 years"', Citywire, 29 May, viewed 09 September 2020, from https:// citywire.co.uk/funds-insider/news/royal-london-s-fox-covid-has-done-more-forcitywire.co.uk/funds-insider/news/royal-london-s-fox
esg-in-10-weeks-than-the-last-10-years/a1361768.

Gottfried, K. \& Donahue, S., 2020, 'The impact of COVID19 on shareholder activism', Harvard Law School Forum on Corporate Governance, viewed 13 May 2020, from https://corpgov.law.harvard.edu/.

Greyser, S.A., 2009, 'Corporate brand reputation and brand crisis management', Management Decision 47(4), 590-602. https://doi.org/10.1108/00251740910 959431

Institute of Directors in Southern Africa (IODSA), 2011, Code for responsible investing in South Africa (CRISA), viewed 21 January 2018, from https://c.ymcdn.com/sites/ www.iodsa.co.za/resource/resmgr/crisa/crisa_19_july_2011.pdf.

Institute of Directors in Southern Africa (IoDSA), 2016, King IV report on corporate governance for South Africa, viewed 18 April 2019, from https://c.ymcdn.com/ sites/iodsa.site-ym.com/resource/collection/684B68A7-B768-465C-8214E3A007F15A5A/loDSA_King_IV_Report_-_WebVersion.pdf.

Ivanova, M.R., 2017, 'Institutional investors as stewards of the corporation: Exploring the challenges to the monitoring hypothesis', Business Ethics: A European Review 26(2), 175-188. https://doi.org/10.1111/beer.12142

Jensen, M.C. \& Meckling, W.H., 1976, 'Theory of the firm: Managerial behavior, agency costs and ownership structure', Journal of Financial Economics 3(4), 305-360. https://doi.org/10.1016/0304-405X(76)90026-X

Johannesburg Stock Exchange (JSE), 2015, JSE announces ESG partnership with FTSE Russell, viewed 11 September 2020, from https://www.jse.co.za/services/marketdata/indices/socially-responsible-investment-index.

Johannesburg Stock Exchange (JSE), 2017, JSE limited listings requirements, viewed 11 September 2020, from https://www.jse.co.za/content/JSERules PoliciesandRegulationltems/JSE\%20Listings\%20Requirements.pdf. 
Johannesburg Stock Exchange (JSE), 2020, Articles, 30 March, viewed 14 May 2020, from https://www.jse.co.za/articles/jse-and-tms-launch-first-virtual-agms-enablingclients-to-engage-with-shareholders.

Just Share, 2020a, Covid-19 shows us that executive pay cuts are possible, 16 April, viewed 14 May 2020, from https://justshare.org.za/.

Just Share, 2020b, Best practices for South African virtual annual general meetings, viewed 14 May 2020, from https://mcusercontent.com/f6ca544c655eaeb 54d175eaed/files/a0295b74-bf19-4737-95d7-05476dc7e509/Just_Share Virtual_AGM_Tips_for_best_practice.01.pdf.

Kennedy-Good, S. \& Chalwin-Milton, A., 2020, 'Electronic AGMs in South Africa: Reacting to a pandemic', Norton Rose Fulbright, 30 March, viewed 20 April 2020, from https://www.financialinstitutionslegalsnapshot.com/2020/03/electronicagms-in-south-africa-reacting-to-a-pandemic/.

Kimbro, M.B. \& Xu, D., 2016, 'Shareholders have a say in executive compensation: Evidence from say-on-pay in the United States', Journal of Accounting and Public Policy 35(1), 19-42. https://doi.org/10.1016/j.jaccpubpol.2015.08.003

Lan, L. \& Heracleous, L., 2010, 'Rethinking agency theory: The view from law', Academy of Management Review 35(2), 294-314. https://doi.org/10.5465/amr. 35.2.zok294

Lang, M. \& Maffett, M., 2011, 'Transparency and liquidity uncertainty in crisis periods', Journal of Accounting and Economics 52(2), 101-125. https://doi.org/10.1016/j. jacceco.2011.07.001

Larkin, P., 2020, 'JSE launches virtual AGMs - Historic first for SA', IOL, 31 March viewed 14 May 2020, from https://www.iol.co.za/business-report/jse-launchesvirtual-agms-historic-first-for-sa-45767901.

Levit, D., 2019, 'Soft shareholder activism', The Review of Financial Studies 32(7), 2775-2808. https://doi.org/10.1093/rfs/hhy119

Loop, P., Bromilow, C. \& Malone, L., 2018, 'The changing face of shareholder activism', Harvard Law School Forum on Corporate Governance, viewed 20 April 2020, from https://corpgov.law.harvard.edu/2018/02/01/the-changing-face-of-shareholderactivism/.

Maruca, R.F., 2000, 'Are ClOs obsolete?', Harvard Business Review, March/April, viewed 15 May 2020, from https://hbr.org/2000/03/are-cios-obsolete.

McCahery, J.A., Sautner, Z. \& Starks, L.T., 2016, 'Behind the scenes: The corporate governance preferences of institutional investors', The Journal of Finance $71(6)$ 2905-2932. https://doi.org/10.1111/jofi.12393

McNulty, T. \& Nordberg, D., 2016, 'Ownership, activism and engagement: Institutional investors as active owners', Corporate Governance: An International Review 24(3), 346-358. https://doi.org/10.1111/corg.12143

Moon, M.J., 2020, 'Fighting COVID-19 with agility, transparency, and participation: Wicked policy problems and new governance challenges', Public Administration Review 80(4), 651-656. https://doi.org/10.1111/puar.13214

Nix, P. \& Chen, J.J., 2013, The role of institutional investors in corporate governance: An empirical study, Palgrave Macmillan, Basingstoke.

Oh, C.H., Park, J. \& Ghauri, P.N., 2013, 'Doing right, investing right: Socially responsible investing and shareholders activism in the financial sector', Business Horizons 56(6), 703-714. https://doi.org/10.1016/j.bushor.2013.07.006

O'Reilly, M. \& Parker, N., 2013, “"Unsatisfactory saturation”: A critical exploration of the notion of saturated sample sizes in qualitative research', Qualitative Research 13(2), 190-197. https://doi.org/10.1177/1468794112446106

Organisation for Economic Co-operation and Development (OECD), 2011, The role of institutional investors in promoting good corporate governance, viewed 01 April 2018, from https://www-oecd-ilibrary-org.ez.sun.ac.za/governance/therole-of-institutional-investors-in-promoting-good-corporate-governance_ 9789264128750-en.

Orol, R., 2020, 'Activist investing today: V\&E's Elbaum on Covid-19 vs. 2008', The Deal, 13 March, viewed 25 April 2020, from https://www.thedeal.com/podcasts/ activist-investing-today-elbaum-on-covid-19-vs-2008/.
Purcell, N., 2008, 'Risk management: Empowering shareholders - Unlocking the power of webcasting and electronic communications', Keeping Good Companies 60(5), 275-279.

Republic of South Africa, 2009, 'Companies Act No 71 of 2008', Government Gazette, 9 April, viewed 15 May 2020, from https://www.gov.za/sites/default/files/gcis_ document/201409/321214210.pdf.

Romano, R., 2001, 'Less is more: Making institutional investor activism a valuable mechanism of corporate governance', Yale Journal on Regulation 18(2), 174-251.

Sampei, H., 2018, 'ESG awareness is an enduring legacy of the global financial crisis', Fidelity International, 12 September, viewed 09 September 2020, from https:// www.fidelityinternational.com/editorial/blog/pesg-awareness-is-an-enduringlegacy-of-the-global-financial-crisisp-a5a9f2-en5/.

Sandberg, J., 2013, '(Re-)interpreting fiduciary duty to justify socially responsible investment for pension funds?', Corporate Governance: An International Review 21(5), 436-446. https://doi.org/10.1111/corg.12028

Schueth, S., 2003, 'Socially responsible investing in the United States', Journal of Business Ethics 43(3), 189-194. https://doi.org/10.1023/A:1022981828869

Semenova, N. \& Hassel, L.G., 2019, 'Private engagements by Nordic institutional investors on environmental, social and governance in global companies', Corporate Governance: An International Review 27(2), 1-18. https://doi.org/10.1111/corg. 12267

Sjöström, E., 2020, 'Active ownership on environmental and social issues: What works? A summary of the recent academic literature', Mistra Center for Sustainable Markets / Stockholm School of Economics, viewed 15 May 2020, from https:// www.stockholmsustainablefinance.com/active-ownership-on-environmental-andsocial-issues-what-works-ssfc-pdf/.

Sparks, J., 2020, 'Investments in times of crisis: ESG comes to the fore', HSBC, 17 April, viewed 10 September 2020, from https://www.hsbcprivatebank.com/en/ discover/news-room/2020/investments-in-time-of-crisis.

Tomlinson, B., Bertrand, A. \& Martindale, W., 2017, 'Fiduciary duty in the 21st century - South Africa roadmap', viewed 09 September 2020, from https://www. unepfi.org/publications/regions-publications/africa-middle-east-publications/ fiduciary-duty-in-the-21st-century-south-africa-roadmap/.

Uldam, J., 2018, 'Social media visibility: Challenges to activism', Media, Culture \& Society 40(1), 41-58. https://doi.org/10.1177/0163443717704997

Viviers, S., Bosch, J.K., Smit, E.V.D.M. \& Buijs, A., 2008, 'Is responsible investment ethical?', South African Journal of Business Management 39(1), 15-25. https:// doi.org/10.4102/sajbm.v39i1.552

Viviers, S. \& Els, G., 2017, 'Responsible investing in South Africa: Past, present and future', African Review of Economics and Finance 9(1), 122-155.

Viviers, S., Mans-Kemp, N. \& Fawcett, R., 2017, 'Mechanisms to promote board gender diversity in South Africa', Acta Commercii 17(1), a489. https://doi.org/ gender diversity in Sout
10.4102/ac.v17i1.489

Viviers, S., Mans-Kemp, N., Kallis, L. \& McKenzie, K., 2019, 'Public "say on pay" activism in South Africa: Targets, challengers, themes and impact', South African Journal of Economic and Management Sciences 22(1), a3251. https://doi. org/10.4102/sajems.v22i1.3251

Viviers, S. \& Smit, E., 2015, 'Institutional proxy voting in South Africa: Processes, outcomes and impact', South African Journal of Business Management 46(3), 23-34. https://doi.org/10.4102/sajbm.v46i4.106

Viviers, S. \& Theron, E., 2019, 'The effect of public investor activism on trust: A case study in the asset management sector', Journal of Economic and Financia Sciences 12(1), 1-14. https://doi.org/10.4102/jef.v12i1.199

Yamahaki, C. \& Frynas, J.G., 2016, 'Institutional determinants of private shareholder engagement in Brazil and South Africa: The role of regulation', Corporate Governance: An International Review 24(5), 509-527. https://doi.org/10.1111/ corg.12166

Zhang, Q., 2016, 'Corporate governance, institutional investors and firm performance: A comparative study of South Africa and China', Unpublished doctoral dissertation, Department of Business Management, Stellenbosch University. 